\title{
EFFECT OF DRYING KINETICS ON COLOR OF "DEDO DE MOÇA" CHILI PEPPERS (Capsicum baccatum)
}

\author{
Ednilton T. de Andrade ${ }^{1 *}$, Vitor G. Figueira ${ }^{2}$, Luciana P. Teixeira ${ }^{3}$, Ana Paula Martinazzo ${ }^{4}$, \\ Kátia G. de L. Araujo ${ }^{4}$
}

${ }^{1 *}$ Corresponding author. Universidade Federal de Lavras/ Lavras - MG, Brasil.

E-mail: ednilton@deg.ufla.br | ORCID ID: https://orcid.org/0000-0002-8448-8781

\section{KEYWORDS}

dehydration, hue angle, quality, Midilli model.

\begin{abstract}
This study aimed to assess the drying kinetics of red and yellow chili peppers, "dedo-demoça" variety, at different temperatures $\left(35,45,55\right.$, and $\left.70{ }^{\circ} \mathrm{C}\right)$ and model this phenomenon mathematically. We also evaluated the effect of these drying air temperatures on pepper fruit color. Pepper fruits were dried in a forced-air circulation dryer. Ten mathematical models were fitted to the experimental data by nonlinear regression analysis. After drying, pepper samples were analyzed for the following colorimetric parameters: lightness ( $\left.\mathrm{L}^{*}\right)$, chroma or saturation (c), and hue angle $(\mathrm{h})$, in order to determine the influence of drying air temperature on fruit coloration. Our findings showed that the higher the air temperature, the faster the drying process. Midilli model fitted well to all temperature data and best represented the drying kinetics of "dedo-demoça" chili peppers. Moreover, fruit color was affected by the drying air temperatures, in which the higher the drying air temperature, the greater the color variation.
\end{abstract}

\section{INTRODUCTION}

Chili peppers are currently grown on family farms and have been responsible for bringing jobs and income to rural areas. Socioeconomically, chili pepper cultivation allows the settling of small farmers and respective families in rural areas and leads to seasonal labor hiring during harvest time (Veras et al., 2012). Another important market is processed and industrialized pepper, which includes dehydrated pepper fruits. This market is underestimated due to the great diversity of products and number of regionally active small companies (Henz \& Ribeiro, 2008).

Chili peppers have vitamins, flavonoids, carotenoids, and other secondary metabolites with antioxidant properties, which reduce the risk of cancer or other chronic degenerative diseases. In addition, they have ascorbic acid and beta-carotene with proven pharmacological effects such as cholesterol reduction and appetite suppression (Veras et al., 2012). "Dedo-de-moça" is a variety of Capsicum baccatum highly perishable, so it needs to undergo processes to extend its shelf life and improve its handling, transport, and storage conditions. One example of such processes is fruit drying (Veras et al., 2012).
Drying is the most widely used process to ensure farm product quality and stability. This is because it reduces moisture content and hence biological activity and chemical and physical changes during storage (Silva \& Rodovalho, 2012; Martinazzo et al., 2007). This process is among the conservation techniques used to maintain the desired quality for plant-origin products harvested with high moisture content (Almeida et al., 2013; Goneli et al., 2014). Storing products with high moisture level leads to growth of microorganisms, which induce fermentation and toxin-contamination thereof, which depreciate and hinders their marketing.

Drying curves show a set of information that is critical for process designing and equipment sizing. These data help determine the time needed to dry a given volume. Hence, this time can be used to estimate energy consumption and process costs, thus affecting the final price of the product (Vilela \& Artur, 2008).

There is a lack of studies in the literature on drying kinetics and their effect on "dedo-de-moça" fruit color. Thus, this study aimed to evaluate the drying kinetics of "dedo-de-moça" pepper fruits, fit different mathematical models to the experimental data, and select the best one, besides evaluating its effect on fruit color.

\footnotetext{
${ }^{2}$ Companhia Nacional de Abastecimento/ Brasília - DF, Brasil.

${ }^{3}$ Universidade Santa Úrsula/ Rio de Janeiro - RJ, Brasil.

${ }^{4}$ Universidade Federal Fluminense/ Niterói - RJ, Brasil.

Received in: 3-31-2017

Accepted in: 9-5-2019
} 


\section{MATERIAL AND METHODS}

The study was developed at the School of Engineering at Universidade Federal Fluminense, NiteróiRJ, Brazil.

"Dedo-de-Moça" chili peppers (Capsicum baccatum) from São Paulo state, purchased from the Centro de Abastecimento do Estado da Guanabara (CADEG-RJ, Guanabara State Supply Center) were used in the experiment. We endeavored to select fruits with the same visual ripening characteristics, in terms of color and shape. These fruits were always obtained from the same sales point. Then, the samples were packaged in plastic bags and transported for about 1 hour at room temperature to the laboratory, wherein they were stored in airtight containers under refrigeration, until the beginning of the experiment.

We cut the pepper fruits with a stainless-steel knife lengthwise in four parts to obtain 1-cm-thick flat pieces. Then, these materials were dried in a lab stationary dryer at air temperatures of about $35,45,55$, and $70{ }^{\circ} \mathrm{C}$, under air circulation heated by a set of lamps. This lab dryer was designed and manufactured by the research team itself, and it had an accuracy of $\pm 0.1{ }^{\circ} \mathrm{C}$. Mean relative air humidity was $63.15 \%$ and mean ambient temperature $23{ }^{\circ} \mathrm{C}$. A digital thermo-hygrograph was used to measure ambient air temperature and relative humidity. Relative humidity inside the dryer was measured using GRAPSI ${ }^{\circledR}$ software.

A rotary vane anemometer was used to monitor drying airspeed at the fan inlet, which was kept constant at about $1 \mathrm{~m} . \mathrm{s}^{-1}$ throughout drying. Moisture loss was monitored by periodic weighing of samples (every 0.5 hours) from the start of testing, using GEHAKA BK600 precision scale. After, weighing was done at regular intervals until reaching constant weight. We determined moisture content of pepper fruit samples using the laboratory oven method at $105 \pm 1^{\circ} \mathrm{C}$ for 24 hours through the gravimetric method, according to analytical standards of the Adolfo Lutz Institute (1985).

Data gathered during drying were used to plot a drying curve as a function of time. The parameters for the fitted mathematical models were estimated by nonlinear modeling (Quasi-Newton method), using the STATISTICA 5.0 software. Table 1 lists the ten empirical and semi-empirical equations (Corrêa et al., 2007; Doymaz, 2006; Mohapatra \& Rao, 2005; Lahsasni et al., 2004; Midilli et al., 2002; Panchariya et al., 2002; Ozdemir \& Devres, 1999) used to fit models for drying kinetics to experimental data (Sousa et al., 2015; Sousa et al., 2014; Goneli et al., 2014; Siqueira et al., 2013).

TABLE 1. Mathematical models used to predict the drying kinetics of agricultural products.

\begin{tabular}{llc}
\hline \multicolumn{1}{c}{ Model name } & \multicolumn{1}{c}{ Model equation } & Eq. $^{\circ}$ \\
\hline Page & $\mathrm{MC}=\exp \left(-\mathrm{kt}^{\mathrm{n}}\right)$ & $(1)$ \\
Approximation of Diffusion & $\mathrm{MC}=\mathrm{aexp}(-\mathrm{kt})+(1-\mathrm{a}) \exp (-\mathrm{kbt})$ & $(2)$ \\
Two Term & $\mathrm{MC}=\mathrm{a} \exp \left(-\mathrm{k}_{0} \mathrm{t}\right)+\mathrm{bexp}\left(-\mathrm{k}_{1} \mathrm{t}\right)$ \\
Two Term Exponential & $\mathrm{MC}=\mathrm{a} \exp (-\mathrm{kt})+(1-\mathrm{a}) \exp (-\mathrm{kat})$ \\
Henderson and Pabis & $\mathrm{MC}=\mathrm{aexp}(-\mathrm{kt})$ & $(4)$ \\
Modified Henderson and Pabis & $\mathrm{MC}=\mathrm{aexp}(-\mathrm{kt})+\mathrm{bexp}\left(-\mathrm{k}_{0} \mathrm{t}\right)+\mathrm{cexp}\left(-\mathrm{k}_{1} \mathrm{t}\right)$ \\
Logarithmic & $\mathrm{MC}=\mathrm{aexp}(-\mathrm{kt})+\mathrm{c}$ \\
Midilli & $\mathrm{MC}=\mathrm{aexp}\left(-\mathrm{kt} \mathrm{t}^{\mathrm{n}}\right)+\mathrm{bt}$ \\
Thompson & $\mathrm{MC}=\exp \left(\left(-\mathrm{a}\left(\mathrm{a}^{2}+4 \mathrm{bt}\right)^{0.5}\right) / 2 \mathrm{~b}\right)$ \\
Verna & $\mathrm{MC}=\mathrm{aexp}(-\mathrm{kt})+(1-\mathrm{a}) \exp (-\mathrm{kt})$ & $(5)$ \\
\hline
\end{tabular}

In which,

$\mathrm{MC}$ - product moisture content, dimensionless;

$\mathrm{t}$ - drying time, $\mathrm{h}$;

$\mathrm{k}, \mathrm{k}_{0}, \mathrm{k}_{1}$ - drying coefficients, $\mathrm{h}^{-1}$,

$\mathrm{a}, \mathrm{b}, \mathrm{c}, \mathrm{n}-$ model constants, dimensionless.

Moisture contents (MC) during drying at different temperatures were calculated as follows:

$$
\mathrm{MC}=(\mathrm{U}-\mathrm{Ue}) /(\mathrm{Ui}-\mathrm{Ue})
$$

In which,

$\mathrm{U}$ - product moisture content, decimal db;

$\mathrm{Ui}$ - initial product moisture content, decimal db,

Ue - equilibrium product moisture content, decimal $\mathrm{db}$.
Equilibrium moisture content (Ue) was estimated by [eq. (12)], described by the model (determined by Andrade).

$\mathrm{U}_{\mathrm{e}}=\exp \left(\left(-3.7576 \mathrm{RH}-\mathrm{T}^{0.2733}+\left(\frac{\mathrm{T}-\mathrm{RH}}{\mathrm{RH}}\right)^{0.2733}\right)\right)^{-0.2978}$

In which,

$\mathrm{U}_{\mathrm{e}}$ - equilibrium product moisture content, $\mathrm{db}$;

$\mathrm{RH}$ - drying-air relative humidity, decimal,

$\mathrm{T}$ - drying-air temperature, ${ }^{\circ} \mathrm{C}$.

Nature of drying kinetics models was evaluated by comparing experimental data with estimates of each model in order to check to mean relative error (MRE), standard error (SE), and chi-square test $\left(\chi^{2}\right)$, according to with the following equations, respectively (Ryan, 2009).

$$
\mathrm{P}=\frac{100}{\mathrm{n}} \sum \frac{\left|\mathrm{Y}-\mathrm{Y}_{0}\right|}{\mathrm{Y}}
$$




$$
\begin{aligned}
& \mathrm{SE}=\sqrt{\sum \frac{\left(\mathrm{Y}-\mathrm{Y}_{0}\right)^{2}}{\mathrm{DF}}} \\
& \chi^{2}=\sum \frac{\left(\mathrm{Y}-\mathrm{Y}_{0}\right)^{2}}{\mathrm{DF}}
\end{aligned}
$$

In which,

$\mathrm{Y}$ - experimentally observed value, dimensionless;

$\mathrm{Y}_{0}$ - model calculated value, dimensionless;

n - number of experimental observations,

DF - degrees of freedom of the model.

For Goneli et al. (2014) and Teixeira et al. (2012), the capacity of a model to describe physical processes faithfully is inversely proportional to the standard deviation (SD) of estimate. Model fit quality considers the magnitudes of determination coefficient $\left(\mathrm{R}^{2}\right)$, mean relative error (MRE), and standard error (SE).

According to Corrêa et al., (2001), water removal rate (WRR) is defined as the amount of water lost by a given product per unit of dry matter and unit of time, as in [eq. (16)].

$$
\mathrm{WRR}=\left(\mathrm{Ma}_{o}-\mathrm{Ma}_{i}\right) /\left(M_{s}\left(t_{i}-\mathrm{t}_{o}\right)\right.
$$

In which,

WRR - water removal rate $(1 \mathrm{~kg}$ water per $\mathrm{kg}$ product per hour), in $\mathrm{kg} . \mathrm{kg}^{-1} \cdot \mathrm{h}^{-1}$;

$\mathrm{Ma}_{\mathrm{o}}$ - total previous water mass, in $\mathrm{kg}$;

$\mathrm{Ma}_{\mathrm{i}}$ - total current water mass, in $\mathrm{kg}$;

$\mathrm{M}_{\mathrm{s}}$ - dry matter, in $\mathrm{kg}$;

$t_{0}$ - total previous drying time, in $h$,

$t_{i}$ - total current drying time, in $h$.

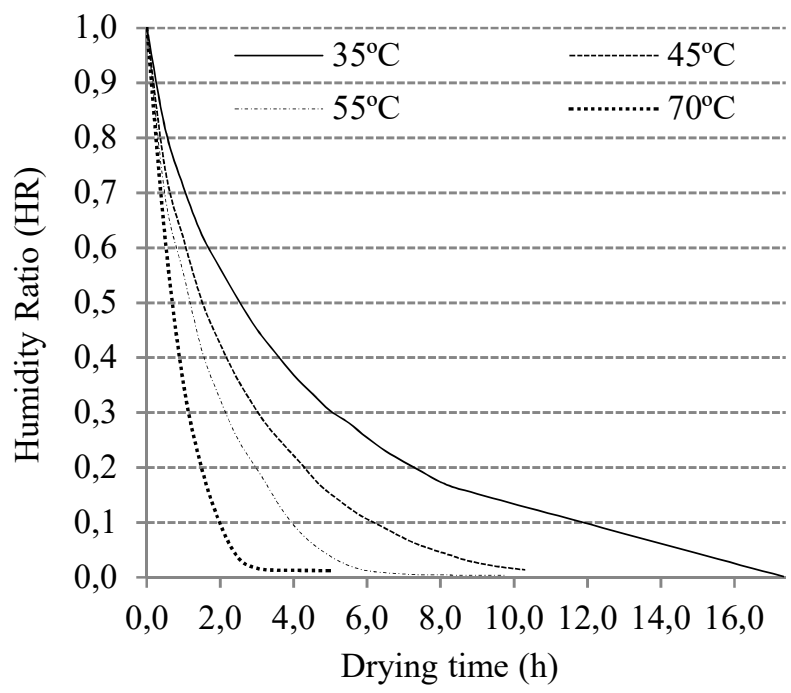

(a)
Fruit color was assessed by direct reflectance reading of coordinates $\mathrm{L} *, \mathrm{a} *, \mathrm{~b} *$ using reflectance spectrophotometer (BYK-GARDNER Color-view 9000) connected to a microcomputer with OnColor for Windows software 5.4.7.9. For each analysis, seven repetitions were performed.

Currently, the CIELAB color system is the most widely used for the characterization of colors in human perception. In this system, $a^{*}$ ranges from green $\left(-a^{*}\right)$ to red $\left(+a^{*}\right), b^{*}$ from blue $\left(-b^{*}\right)$ to yellow $\left(+b^{*}\right)$, and $L^{*}$ (lightness) from 0 (black) to $100 \%$ (white) (Régula, 2004; Autran \& Gonçalez, 2006; Guiné et al., 2010). Color differences between two samples in the same situation, or a single sample in two different situations, are commonly assessed by calculating hue angle (h) and chroma (C) (Moura et al., 2014; Oliveira et al. al., 2012).

Chroma is zero in the center of the color axis and increases with distance. Hue angle starts at the $\mathrm{a}^{*}$ axis and is expressed in degrees. The $\mathrm{h}$ is zero when $+\mathrm{a}^{*}$ (red), $90^{\circ}$ is defined as $+\mathrm{b}^{*}$ (yellow), $180^{\circ}$ is $-\mathrm{a}^{*}$ (green), and $270^{\circ}$, $\mathrm{b} *$ is blue (Moura et al., 2014). However, these coordinates are not independent variables and should not be analyzed directly.

$$
\mathrm{h}=\tan ^{-1}\left(\frac{\mathrm{b}^{*}}{\mathrm{a}^{*}}\right)
$$

$$
\mathrm{C}=\left[\left(\mathrm{a}^{*}\right)^{2}+\left(\mathrm{b}^{*}\right)^{2}\right]^{\frac{1}{2}}
$$

\section{RESULTS AND DISCUSSION}

Figure 1 ( $a$ and $b$ ) show the drying curves at different air temperatures for yellow and red "dedo de moça" pepper, respectively. The graphs show that drying time decreases with increasing air temperature.

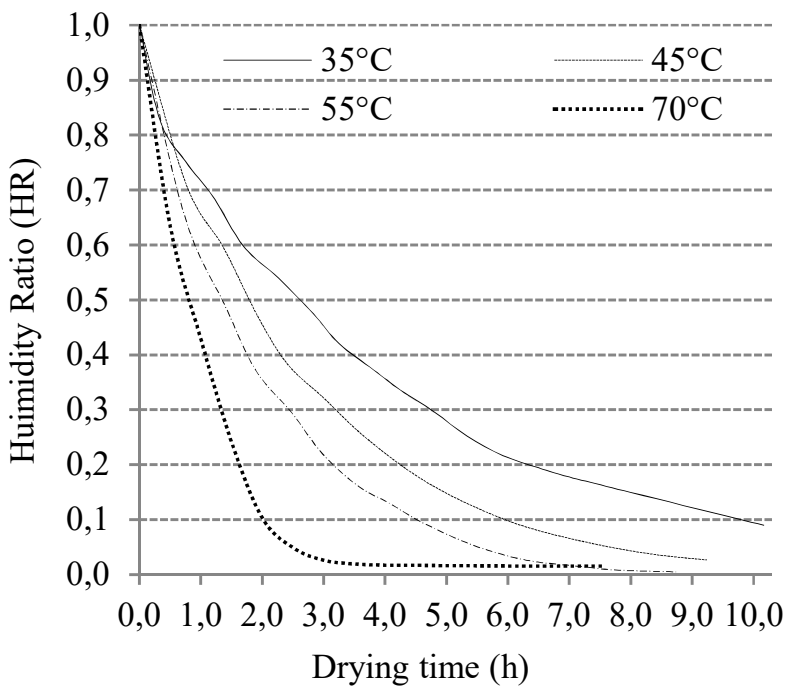

(b)

FIGURE 1. Moisture ratio as a function of time at different drying air temperatures for red (a) and yellow (b) "dedo de moça" chili peppers. 
Drying kinetics was modeled using the models in Table 1, determining their respective parameters, coefficients of determination $\left(\mathrm{R}^{2}\right)$, mean relative error $(\mathrm{P})$, mean estimated error $(\mathrm{SE})$, and chi-square test $\left(\chi^{2}\right)$. Tables 2 to 5 below show the parameters of the models fitted to the drying kinetics of red and yellow "dedo de moça" chili peppers for each drying temperature.

TABLE 2. Parameters of the models fitted to the drying data of red and yellow "dedo de moça" chili peppers at drying air temperature of $35^{\circ} \mathrm{C}$

\begin{tabular}{|c|c|c|c|c|c|c|c|c|c|c|c|}
\hline \multicolumn{12}{|c|}{ Yellow } \\
\hline Model & $\mathrm{a}$ & b & $\mathrm{c}$ & $\mathrm{k}$ & k0 & $\mathrm{k} 1$ & $\mathrm{~N}$ & $\begin{array}{l}\mathrm{R}^{2} \\
(\%)\end{array}$ & $\begin{array}{c}\mathrm{P} \\
(\%) \\
\end{array}$ & $\begin{array}{c}\text { SE } \\
\text { (decimal) }\end{array}$ & $\begin{array}{c}\chi^{2} \\
\text { (decimal) } \\
\end{array}$ \\
\hline (1) & & & & 0.3337 & & & 0.7943 & 99.85 & 0.64 & 0.0160 & 0.0003 \\
\hline (2) & 0.1853 & 0.1204 & & 1.6232 & & & & 99.92 & 0.67 & 0.0087 & 0.0001 \\
\hline (3) & 0.4624 & 0.4624 & & & 0.2255 & 0.2255 & & 98.91 & 4.00 & 0.0608 & 0.0037 \\
\hline (4) & 0.1718 & & & 1.1776 & & & & 99.77 & 1.73 & 0.0433 & 0.0019 \\
\hline (5) & 0.9248 & & & 0.2255 & & & & 98.91 & 4.00 & 0.1052 & 0.0111 \\
\hline (6) & 0.3083 & 0.3083 & 0.3083 & 0.2255 & 0.2255 & 0.2255 & & 98.91 & 4.00 & 0.0471 & 0.0022 \\
\hline (7) & 0.8964 & & 0.0409 & 0.2513 & & & & 99.05 & 3.35 & 0.0630 & 0.0040 \\
\hline (8) & 1.0003 & -0.0031 & & 0.3390 & & & 0.7510 & 99.99 & 0.32 & 0.0042 & 0.0000 \\
\hline (9) & 0.1421 & 0.0826 & & & & & & 91.50 & 11.21 & 0.2663 & 0.0709 \\
\hline (10) & 0.1000 & & & 0.2480 & & & & 97.75 & 6.71 & 0.1509 & 0.0228 \\
\hline \multicolumn{12}{|c|}{ Red } \\
\hline (1) & & & & 0.3329 & & & 0.8313 & 99.57 & 3.80 & 0.0666 & 0.0044 \\
\hline (2) & 0.1008 & 0.0121 & & 19.2378 & & & & 99.95 & 1.59 & 0.0166 & 0.0003 \\
\hline (3) & 0.4684 & 0.4684 & & & 0.2452 & 0.2452 & & 99.33 & 3.11 & 0.0481 & 0.0023 \\
\hline (4) & 0.1011 & & & 2.3185 & & & & 99.67 & 2.21 & 0.0587 & 0.0034 \\
\hline (5) & 0.9368 & & & 0.2452 & & & & 99.33 & 3.11 & 0.0833 & 0.0069 \\
\hline (6) & 0.3123 & 0.3123 & 0.3123 & 0.2452 & 0.2452 & 0.2452 & & 99.33 & 3.11 & 0.0373 & 0.0014 \\
\hline (7) & 0.9061 & & 0.0390 & 0.2693 & & & & 99.40 & 2.80 & 0.0557 & 0.0031 \\
\hline (8) & 0.9849 & -0.0058 & & 0.3190 & & & 0.7924 & 99.72 & 3.39 & 0.0308 & 0.0009 \\
\hline (9) & 0.2376 & 0.2343 & & & & & & 90.00 & 25.65 & 0.3209 & 0.1030 \\
\hline (10) & 0.1000 & & & 0.2665 & & & & 98.32 & 6.47 & 0.1315 & 0.0173 \\
\hline
\end{tabular}

TABLE 3. Parameters of the models fitted to the drying data of red and yellow "dedo de moça" chili peppers at drying air temperature of $45^{\circ} \mathrm{C}$.

\begin{tabular}{|c|c|c|c|c|c|c|c|c|c|c|c|}
\hline \multicolumn{12}{|c|}{ Yellow } \\
\hline Model & $\mathrm{a}$ & $\mathrm{b}$ & $\mathrm{c}$ & $\mathrm{k}$ & $\mathrm{k} 0$ & $\mathrm{k} 1$ & $\mathrm{~N}$ & $\begin{array}{l}\mathrm{R}^{2} \\
(\%) \\
\end{array}$ & $\begin{array}{c}\mathrm{P} \\
(\%) \\
\end{array}$ & $\begin{array}{c}\text { SE } \\
\text { (decimal) }\end{array}$ & $\begin{array}{c}\chi^{2} \\
\text { (decimal) }\end{array}$ \\
\hline (1) & & & & 0.4827 & & & 0.8489 & 99.84 & 13.07 & 0.0447 & 0.0020 \\
\hline (2) & 0.8619 & 11.0486 & & 0.3499 & & & & 99.96 & 7.22 & 0.0165 & 0.0003 \\
\hline (3) & 0.4723 & 0.4723 & & & 0.3846 & 0.3846 & & 99.40 & 7.06 & 0.0501 & 0.0025 \\
\hline (4) & 0.1479 & & & 2.3592 & & & & 99.93 & 7.43 & 0.0301 & 0.0009 \\
\hline (5) & 0.9446 & & & 0.3846 & & & & 99.40 & 7.06 & 0.0867 & 0.0075 \\
\hline (6) & 0.3149 & 0.3149 & 0.3149 & 0.3846 & 0.3846 & 0.3846 & & 99.40 & 7.06 & 0.0388 & 0.0015 \\
\hline (7) & 0.9340 & & 0.0198 & 0.4103 & & & & 99.47 & 13.75 & 0.0577 & 0.0033 \\
\hline (8) & 0.9982 & -0.0046 & & 0.4862 & & & 0.7849 & 99.98 & 2.80 & 0.0086 & 0.0001 \\
\hline (9) & 0.1410 & 0.0437 & & & & & & 87.60 & 93.16 & 0.3937 & 0.1550 \\
\hline (10) & 0.1000 & & & 0.4094 & & & & 98.97 & 10.06 & 0.1134 & 0.0129 \\
\hline \multicolumn{12}{|c|}{ Red } \\
\hline (1) & & & & 0.4017 & & & 0.9688 & 99.90 & 5.45 & 0.0350 & 0.0012 \\
\hline (2) & 0.9624 & 82.4723 & & 0.3730 & & & & 99.93 & 4.93 & 0.0206 & 0.0004 \\
\hline (3) & 0.4936 & 0.4936 & & & 0.3825 & 0.3825 & & 99.89 & 3.30 & 0.0211 & 0.0004 \\
\hline (4) & 0.7029 & & & 0.4325 & & & & 99.88 & 4.77 & 0.0386 & 0.0015 \\
\hline (5) & 0.9872 & & & 0.3825 & & & & 99.89 & 3.30 & 0.0366 & 0.0013 \\
\hline (6) & 0.3291 & 0.3291 & 0.3291 & 0.3825 & 0.3825 & 0.3825 & & 99.89 & 3.30 & 0.0164 & 0.0003 \\
\hline (7) & 0.9879 & & -0.0013 & 0.3811 & & & & 99.89 & 2.74 & 0.0258 & 0.0007 \\
\hline (8) & 0.9969 & -0.0019 & & 0.4037 & & & 0.9384 & 99.93 & 3.43 & 0.0171 & 0.0003 \\
\hline (9) & 0.1472 & 0.0484 & & & & & & 85.07 & 98.78 & 0.4239 & 0.1797 \\
\hline (10) & 0.1000 & & & 0.3875 & & & & 99.87 & 2.53 & 0.0398 & 0.0016 \\
\hline
\end{tabular}


TABLE 4. Parameters of the models fitted to the drying data of red and yellow "dedo de moça" chili peppers at drying air temperature of $55^{\circ} \mathrm{C}$.

\begin{tabular}{|c|c|c|c|c|c|c|c|c|c|c|c|}
\hline \multicolumn{12}{|c|}{ Yellow } \\
\hline Model & $\mathrm{a}$ & $\mathrm{b}$ & $\mathrm{c}$ & $\mathrm{k}$ & $\mathrm{k} 0$ & $\mathrm{k} 1$ & $\mathrm{~N}$ & $\begin{array}{c}\mathrm{R}^{2} \\
(\%) \\
\end{array}$ & $\begin{array}{c}\mathrm{P} \\
(\%) \\
\end{array}$ & $\begin{array}{c}\mathrm{SE} \\
\text { (decimal) }\end{array}$ & $\begin{array}{c}\chi^{2} \\
\text { (decimal) }\end{array}$ \\
\hline (1) & & & & 0.6131 & & & 0.9355 & 99.66 & 16.62 & 0.0567 & 0.0032 \\
\hline (2) & 0.0717 & 0.0256 & & 21.1809 & & & & 99.79 & 15.36 & 0.0318 & 0.0010 \\
\hline (3) & 0.4887 & 0.4887 & & & 0.5713 & 0.5713 & & 99.61 & 12.95 & 0.0350 & 0.0012 \\
\hline (4) & 0.6152 & & & 0.7129 & & & & 99.56 & 15.38 & 0.0646 & 0.0042 \\
\hline (5) & 0.9773 & & & 0.5713 & & & & 99.61 & 12.95 & 0.0606 & 0.0037 \\
\hline (6) & 0.3258 & 0.3258 & 0.3258 & 0.5713 & 0.5713 & 0.5713 & & 99.61 & 12.95 & 0.0271 & 0.0007 \\
\hline (7) & 0.9852 & & -0.0115 & 0.5533 & & & & 99.62 & 9.82 & 0.0421 & 0.0018 \\
\hline (8) & 0.9986 & -0.0160 & & 0.5905 & & & 0.8025 & 99.95 & 4.46 & 0.0130 & 0.0002 \\
\hline (9) & 0.1713 & 0.0519 & & & & & & 81.92 & 105.99 & 0.4120 & 0.1697 \\
\hline (10) & 0.1000 & & & 0.5851 & & & & 99.53 & 11.95 & 0.0663 & 0.0044 \\
\hline \multicolumn{12}{|c|}{ Red } \\
\hline (1) & & & & 0.5304 & & & 0.9740 & 99.85 & 16.64 & 0.0396 & 0.0016 \\
\hline (2) & 0.0414 & 0.0432 & & 11.5156 & & & & 99.88 & 16.74 & 0.0245 & 0.0006 \\
\hline (3) & 0.4950 & 0.4950 & & & 0.5131 & 0.5131 & & 99.84 & 14.47 & 0.0232 & 0.0005 \\
\hline (4) & 0.8951 & & & 0.5241 & & & & 99.83 & 13.94 & 0.0419 & 0.0018 \\
\hline (5) & 0.9900 & & & 0.5131 & & & & 99.84 & 14.47 & 0.0403 & 0.0016 \\
\hline (6) & 0.3300 & 0.3300 & 0.3300 & 0.5131 & 0.5131 & 0.5131 & & 99.84 & 14.47 & 0.0180 & 0.0003 \\
\hline (7) & 0.9966 & & -0.0105 & 0.4974 & & & & 99.86 & 7.23 & 0.0267 & 0.0007 \\
\hline (8) & 0.9985 & -0.0049 & & 0.5342 & & & 0.9053 & 99.95 & 6.43 & 0.0128 & 0.0002 \\
\hline$(9)$ & 0.1460 & 0.0368 & & & & & & 82.90 & 159.30 & 0.4195 & 0.1760 \\
\hline (10) & 0.1000 & & & 0.5179 & & & & 99.83 & 13.81 & 0.0419 & 0.0018 \\
\hline
\end{tabular}

TABLE 5. Parameters of the models fitted to the drying data of red and yellow "dedo de moça" chili peppers at drying air temperature of $70^{\circ} \mathrm{C}$.

\begin{tabular}{|c|c|c|c|c|c|c|c|c|c|c|c|}
\hline \multicolumn{12}{|c|}{ Yellow } \\
\hline Model & $\mathrm{a}$ & $\mathrm{b}$ & $\mathrm{c}$ & $\mathrm{k}$ & $\mathrm{k} 0$ & $\mathrm{k} 1$ & $\mathrm{~N}$ & $\begin{array}{l}\mathrm{R}^{2} \\
(\%)\end{array}$ & $\begin{array}{c}\mathrm{P} \\
(\%)\end{array}$ & $\begin{array}{c}\text { SE } \\
\text { (decimal) }\end{array}$ & $\begin{array}{c}\chi^{2} \\
\text { (decimal) }\end{array}$ \\
\hline (1) & & & & 1.0520 & & & 1.1509 & 99.95 & 6.69 & 0.0188 & 0.0004 \\
\hline (2) & 0.6095 & 1.0000 & & 1.0757 & & & & 99.60 & 17.63 & 0.0365 & 0.0013 \\
\hline (3) & 0.5075 & 0.5075 & & & 1.0899 & 1.0899 & & 99.63 & 16.85 & 0.0286 & 0.0008 \\
\hline (4) & 1.0000 & & & 1.0757 & & & & 99.60 & 17.63 & 0.0516 & 0.0027 \\
\hline (5) & 1.0150 & & & 1.0899 & & & & 99.63 & 16.85 & 0.0495 & 0.0025 \\
\hline (6) & 0.3383 & 0.3383 & 0.3383 & 1.0899 & 1.0899 & 1.0899 & & 99.63 & 16.85 & 0.0221 & 0.0005 \\
\hline (7) & 1.0626 & & -0.0581 & 0.9434 & & & & 99.95 & 4.57 & 0.0116 & 0.0001 \\
\hline (8) & 0.9998 & -0.0073 & & 1.0199 & & & 1.0985 & 99.98 & 3.95 & 0.0057 & 0.0000 \\
\hline (9) & 0.2082 & 0.0533 & & & & & & 69.14 & 119.74 & 0.4585 & 0.2102 \\
\hline (10) & 0.1000 & & & 1.0757 & & & & 99.60 & 17.63 & 0.0516 & 0.0027 \\
\hline \multicolumn{12}{|c|}{ Red } \\
\hline (1) & & & & 0.9237 & & & 1.1678 & 99.57 & 12.85 & 0.0532 & 0.0028 \\
\hline (2) & 70.7046 & 1.0077 & & 1.5143 & & & & 99.56 & 12.94 & 0.0361 & 0.0013 \\
\hline (3) & 0.5072 & 0.5072 & & & 0.9687 & 0.9687 & & 99.11 & 23.32 & 0.0440 & 0.0019 \\
\hline (4) & 1.6679 & & & 1.2451 & & & & 99.57 & 13.99 & 0.0532 & 0.0028 \\
\hline (5) & 1.0144 & & & 0.9687 & & & & 99.11 & 23.32 & 0.0762 & 0.0058 \\
\hline (6) & 0.3381 & 0.3381 & 0.3381 & 0.9687 & 0.9687 & 0.9687 & & 99.11 & 23.32 & 0.0341 & 0.0012 \\
\hline (7) & 1.1489 & & -0.1523 & 0.7159 & & & & 99.83 & 7.65 & 0.0235 & 0.0006 \\
\hline (8) & 0.9986 & -0.0430 & & 0.7920 & & & 0.9756 & 99.83 & 8.91 & 0.0193 & 0.0004 \\
\hline (9) & 0.1748 & 0.0454 & & & & & & 70.57 & 119.63 & 0.4381 & 0.1919 \\
\hline (10) & 0.1000 & & & 0.9557 & & & & 99.07 & 23.98 & 0.0778 & 0.0060 \\
\hline
\end{tabular}


According to Teixeira et al., (2012), and Mohapatra \& Rao (2005), models showing an unsuitable fit to the experimental data have a mean relative error $(\mathrm{P})$ greater than $10 \%$ and are unable to adequately represent the analyzed phenomenon, and their $\mathrm{R}^{2}$ should be near one.

After evaluating the results in Tables 2 to 5 , we could observe that the Midilli model was the one that best fitted the drying kinetics of "dedo-de-moça" yellow chili pepper at $35,45,55$, and $70{ }^{\circ} \mathrm{C}$, showing greater $\mathrm{R}^{2}$ and lower P, SE, and $\chi^{2}$ values.

As for the red "dedo de moça" chili pepper, Tables 2 to 5 show that the data of drying kinetics were satisfactorily fitted by the approximation of diffusion model at $35{ }^{\circ} \mathrm{C}$, the modified Henderson and Pabis model at $45^{\circ} \mathrm{C}$, and the Midilli model at 55 and $70{ }^{\circ} \mathrm{C}$. Therefore, these models were the ones that best represent the drying phenomenon, with higher $\mathrm{R}^{2}$ and lower $\mathrm{P}, \mathrm{SE}$, and $\chi^{2}$ values.

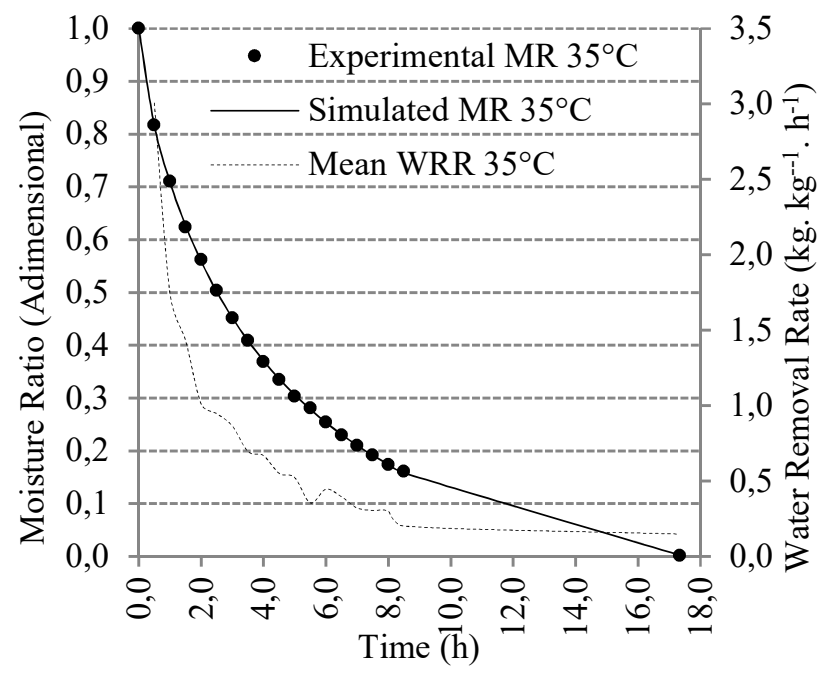

(a)
As a result of ease of use and satisfactory fit, the Midilli model may be used to represent the drying kinetics of yellow and red "dedo de moça" chili peppers. As shown in Tables 2 to 5, this model had $\mathrm{R}^{2}$ above $99.72 \%$, and $\mathrm{P}$, SE, and $\chi^{2}$ values below $8.91 \%, 0.0308$, and 0.0009 , respectively, for all the analyses.

We analyzed the drying curve of yellow and red "dedo-de-moça" chili peppers to observe their drying behavior at each studied temperature, as seen in Figures 2 to 5 below. After that, we fitted the experimental data to different mathematical models that represent the drying phenomenon so that coefficients for drying kinetics equations could be obtained.

The following graphs show the simulated and experimental moisture ratios obtained by the best fit models, showing how well they represent the drying kinetics phenomenon.

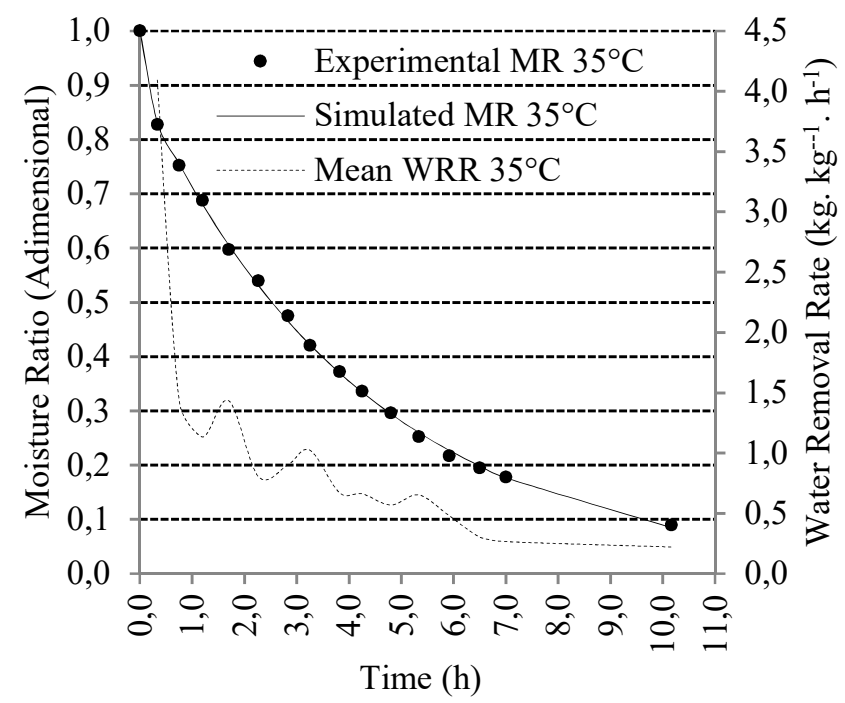

(b)

FIGURE 2. Experimental and simulated moisture ratio curve and water removal rate at $35{ }^{\circ} \mathrm{C}$ for yellow (a) and red (b) "dedo de moça" chili peppers.

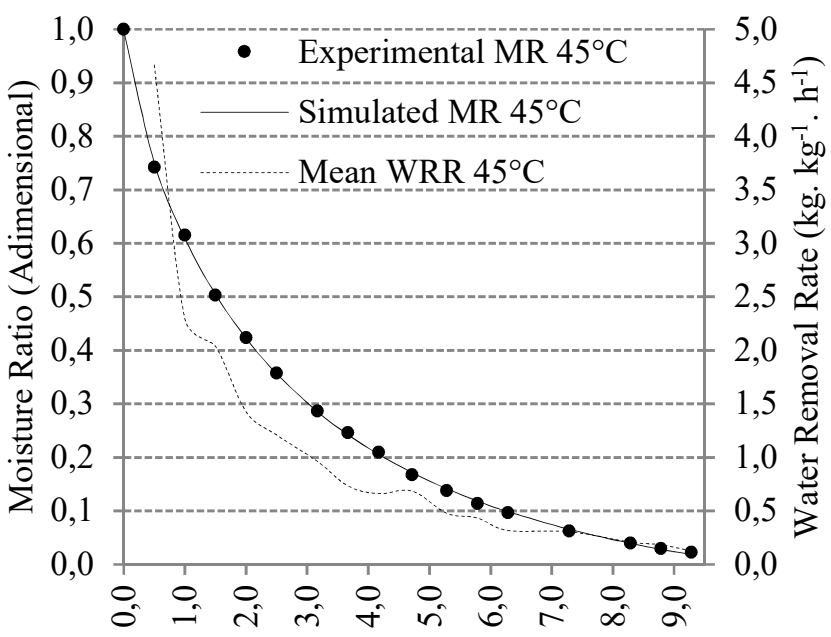

Time (h)

(a)

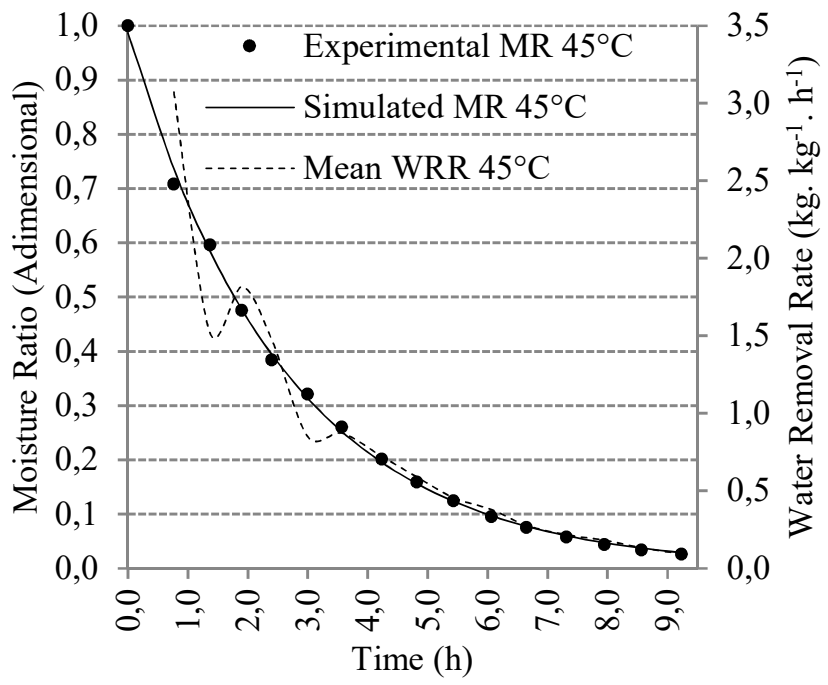

(b)

FIGURE 3. Experimental and simulated moisture ratio curve and water removal rate at $45{ }^{\circ} \mathrm{C}$ for yellow (a) and red (b) "dedo de moça" chili peppers. 


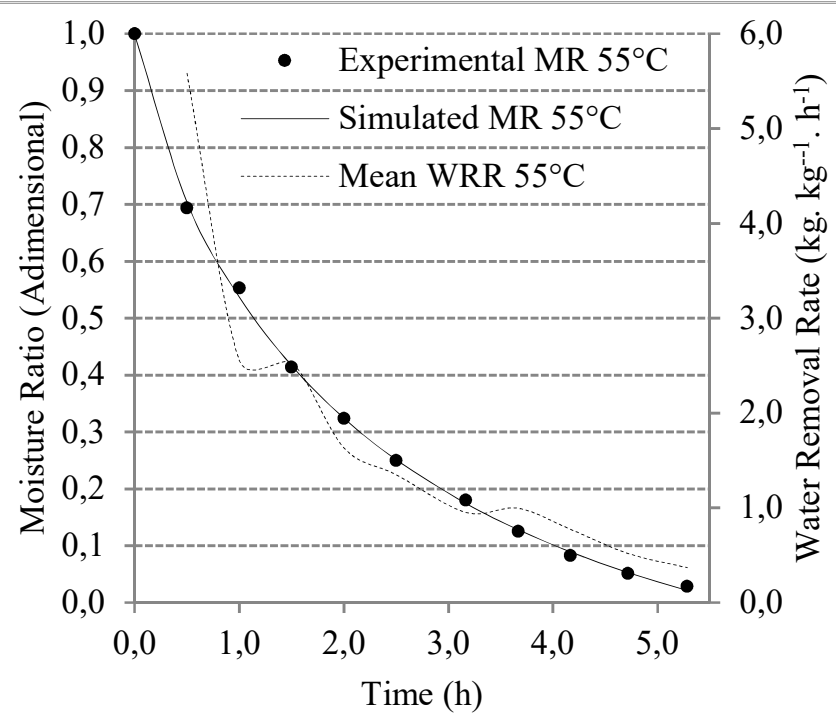

(a)

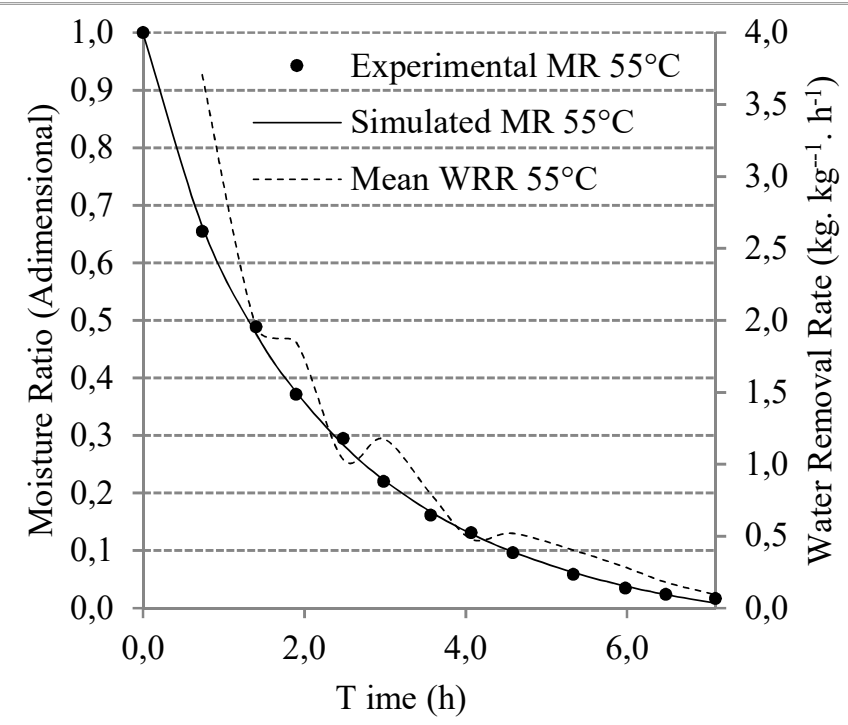

(b)

FIGURE 4. Experimental and simulated moisture ratio curve and water removal rate at $55{ }^{\circ} \mathrm{C}$ for yellow (a) and red (b) "dedo de moça" chili peppers.

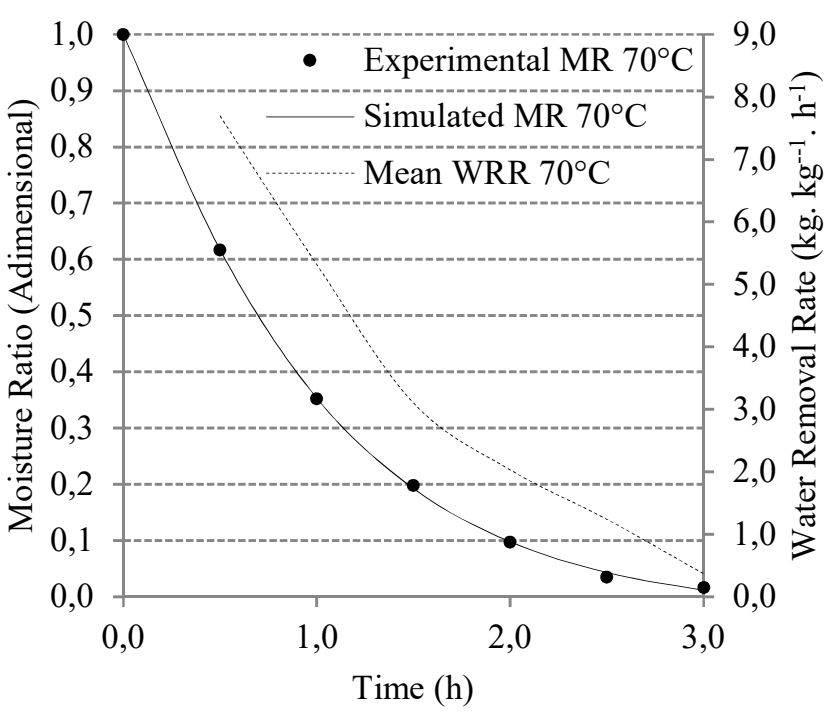

(a)

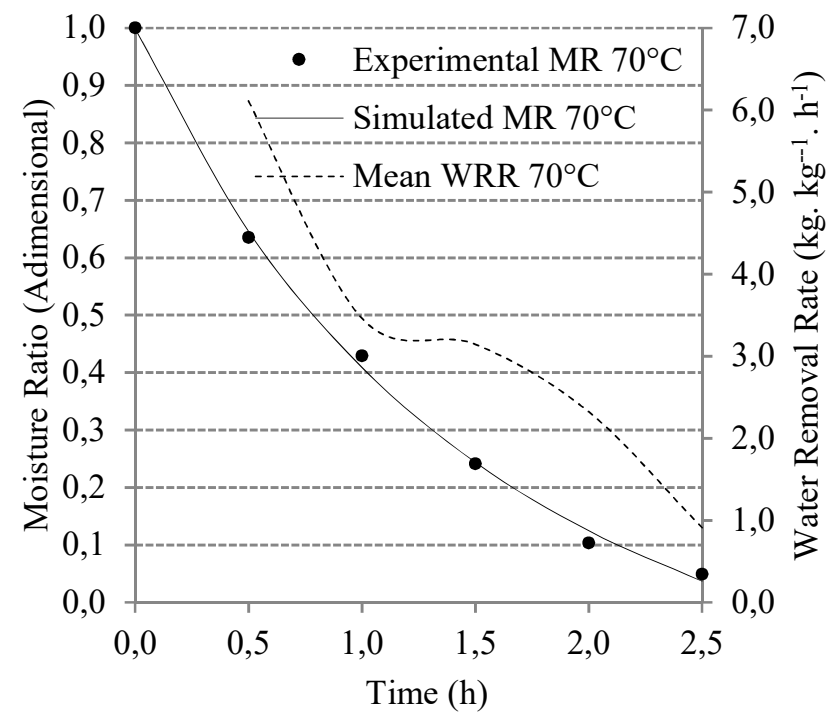

(b)

FIGURE 5. Experimental and simulated moisture ratio curve and water removal rate at $70^{\circ} \mathrm{C}$ for yellow (a) and red (b) "dedo de moça" chili peppers.

Together with experimental and simulated moisture ratio for the model fitted to the phenomenon, we also analyzed the water removal rate to describe water loss per unit dry matter and time. Through water removal data, we observed that drying was homogeneous without peaks or abrupt falls for both yellow and red "dedo-de-moça" chili peppers at all drying air temperatures. Abrupt changes in this parameter show failures in the drying process, e.g. in air temperature control.

Table 6 shows that changes in drying air temperature promoted lighter sample colors due to an increase in $\mathrm{L}^{*}$ coordinate, i.e. an increase in drying air temperatures caused an increase in lightness and, hence, lighter pepper colors.

TABLE 6. Results of lightness $\left(\mathrm{L}^{*}\right)$, redness $\left(\mathrm{a}^{*}\right)$, yellowness $\left(\mathrm{b}^{*}\right)$, chroma $(\mathrm{C})$, and hue angle $(\mathrm{h})$ of color analysis of red "dedo de moça" chili pepper.

\begin{tabular}{clllll}
\hline Temperature $\left({ }^{\circ} \mathbf{C}\right)$ & \multicolumn{1}{c}{$\mathbf{L}^{*}$} & \multicolumn{1}{c}{$\mathbf{a}^{*}$} & \multicolumn{1}{c}{$\mathbf{b}^{*}$} & \multicolumn{1}{c}{$\mathbf{C}$} & $38.99 \mathrm{a}$ \\
55 & $42.51 \mathrm{a}$ & $32.85 \mathrm{a}$ & $26.59 \mathrm{a}$ & $42.26 \mathrm{a}$ & $38.83 \mathrm{a}$ \\
45 & $41.63 \mathrm{ab}$ & $31.72 \mathrm{ab}$ & $25.57 \mathrm{a}$ & $40.77 \mathrm{ab}$ & $35.49 \mathrm{~b}$ \\
35 & $40.10 \mathrm{~b}$ & $29.72 \mathrm{~b}$ & $21.19 \mathrm{~b}$ & $37.19 \mathrm{c}$ & $30.52 \mathrm{c}$ \\
& $38.01 \mathrm{c}$ & $33.43 \mathrm{a}$ & $19.69 \mathrm{~b}$ & $38.81 \mathrm{bc}$ & $\mathrm{CV} \%=4.51$ \\
\hline
\end{tabular}


Chroma (c) increased significantly with increasing drying air temperature, saturating or intensifying red "dedo-de-moça" chili peppers during drying, with the highest value at $70^{\circ} \mathrm{C}$.

Drying air temperature had a significant effect on hue angle (h). Intense red on sample surface was predominantly due to low $\mathrm{h}$ values. An increase in intense red saturation indicates chroma intensity (c) and hue angle (h). Therefore, the closer to zero, the greater the red color intensity. The lower the hue angle, the more intense the red color, and the lower the effect of drying air temperature on red color loss of red "dedo-de-moça" chili peppers. Thus, we conclude that a drying air temperature of $70{ }^{\circ} \mathrm{C}$ has a negative effect on the maintenance of original red color of "dedo-de-moça" chili peppers.

\section{CONCLUSIONS}

Midilli model shows a satisfactory fit to all drying air temperatures studied here; therefore, it can be used to represent drying kinetics of yellow and red "dedo-demoça" chili peppers.

An increase in drying air temperature lightened the red color of pepper samples with reduced lightness $\left(\mathrm{L}^{*}\right)$. A drying air temperature of $70{ }^{\circ} \mathrm{C}$ was detrimental to the maintenance of the original red color of "dedo-de-moça" chili peppers. Thus, based on our findings of pepper colorimetry and drying, temperatures below $55{ }^{\circ} \mathrm{C}$ are recommended for the drying process of "dedo-de-moça" chili peppers.

\section{REFERENCES}

Almeida DP, Resende O, Mendes UC, Costa LM, Corrêa PC, Rocha AC (2013) Influência da secagem na qualidade de sementes de feijão adzuki. Revista Brasileira de Ciências Agrárias 8(2):311-315. DOI:

http://dx.doi.org/10.5039/agraria.v8i2a2164

Autran CS, Gonçalez JC (2006) Caracterização colorimétrica das madeiras de Muirapiranga (BrosimumrubescensTaub.) e de Seringueira (Hevea brasiliensis, clone tjir 16 müll arg.) visando à utilização em interiores. Ciência Florestal 16(4):445-451.

Corrêa PC, Resende O, Martinazo AP, Goneli ALD, Botelho FM (2007) Modelagem matemática para a descrição do processo de secagem do feijão (Phaseolus vulgaris L.) em camadas delgadas. Engenharia Agrícola 27(2):501-510.

Corrêa PC, Machado PF, Andrade ET (2001) Cinética de secagem e qualidade de grãos de milho-pipoca. Ciência e Agrotecnologia 25:134-142

Doymaz I (2006) Thin-layer drying behaviour of mint leaves. Journal of Food Engineering 74(3):370-375.

Goneli ALD, Nasu AK, Gancedo R, Araújo WD, Sarath KLL (2014) Cinética de secagem de folhas de erva baleeira (Cordiaverbenacea). Revista brasileira de plantas medicinais 16(2):434-443. DOI:

http://dx.doi.org/10.1590/1983-084X/13_041

Guiné R, Carrilha F, Loureiro A (2010) Influência do modo de secagem sobre a cor, a textura e a composição nutricional das peras. In Guiné R (ed). Secagem de peras. Da tradição à ciência. Viseu, CI\&DETS, p.173-188.
Henz GP, Ribeiro CS (2008) Mercado e comercialização. In: Ribeiro CS, Lopes CA, Carvalho SI, Henz GP, Reifschneider FJ, Alcântara FA (ed). Pimentas Capsicum. Brasília, Athalaia Gráfica e Editora, v1, p11-12.

Instituto Adolfo Lutz (1985) Normas Analíticas do Instituto Adolfo Lutz. São Paulo.

Lahsasni S, Kouhila M, Mahrouz M, Jaouhari JT (2004) Drying kinetcs of prickly pear fruit (Opuntia ficus indica). Journal of Food Engineering 61(2):173-179.

Martinazzo AP, Corrêa PC, Resende O, Melo EC (2007) Análise e descrição matemática da cinética de secagem de folhas de capim limão. Revista Brasileira de Engenharia Agrícola e Ambiental 11(3):301-306. DOI: http://dx.doi.org/10.1590/S1415-43662007000300009

Midilli A, Kucuk H, Yapar ZA (2002) New model for single-layer drying. Drying Technology 20:1503-1513.

Mohapatra D, Rao PS (2005) A thin layer drying model of parboleid wheat. Journal of Food Engineering 66(4):513518. DOI: http://dx.doi.org/10.1016/j.jfoodeng.2004.04.023

Moura RL, Figueirêdo RMA, Queiroz AJM (2014) Processamento e caracterização físico-química de néctares goiaba-tomate. Revista Verde de Agroecologia e Desenvolvimento Sustentável 9(3):69-75.

Ozdemir M, Devres YO (1999) The thin layer drying characteristics of hazelnuts during roasting. Journal of Food Engineering 42(4):225-233.

Oliveira TA, Aroucha EMM, Souza MSM, Leite RHL, Santos KG (2012) Efeito do biofilme de gelatina e cloreto de cálcio na coloração de quiabo armazenado sob refrigeração. ACSA - Agropecuária Científica no SemiÁrido 8(2):07-11.

Panchariya PC, Popovic D, Sharma AL (2002) Thin-layer modeling of black tea drying process. Journal Food Engineering 52(4):349-357.

Régula LM (2004) Padrões virtuais e tolerâncias colorimétricas no controle instrumental das cores. Dissertação, Mestrado, Rio de Janeiro, Pontifica Universidade Católica.

Ryan T (2009) Estatística moderna para engenharia. Rio de Janeiro, Elsevier Editora, 344p.

Silva HW, Rodovalho RS (2012) Isotermas de dessorção das sementes de pimenta malagueta. Global Science and Technology 5(1):33. DOI: http://dx.doi.org/10.14688/1984-3801/gst.v5n1p32-39

Siqueira VC, Resende O, Chaves TH (2013) Mathematical modelling of the drying of jatropha fruit: an empirical comparison. Revista Ciência Agronômica 44(2):278-285. Doi: http://dx.doi.org/10.1590/S1806-66902013000200009

Sousa FA, Andrade ET, Figueira VG (2014) Estudo da cinética de secagem, contração volumétrica e análise da difusão líquida do morango (Fragaria sp.). Engevista 16(1):8-18. 
Sousa FC, Martins JJA, Rocha APT, Gomes JP, Pessoa T, Martins JN (2015) Predição de modelos sobre a cinética de secagem de folhas de Ziziphus joazeiro Mart. Revista Brasileira de Plantas Medicinais 17(2):195-200. DOI: http://dx.doi.org/10.1590/1983-084X/12_071

Teixeira LP, Andrade ET, Silva PG (2012) Determinação do equilíbrio higroscópico e do calor isostérico da polpa e da casca do abacaxi (Ananas comosus). Engevista 14(2): 172-184.
Veras AOM, Béttega R, Freire FB, Barrozo MAS, Freire JT (2012) Drying kinetics, structural characteristics and vitamin C retention of dedo-de-moça pepper (Capsicum baccatum) during convective and freeze drying. Brazilian Journal of Chemical Engineering (Impresso) 29(4):741-750. DOI: http://dx.doi.org/10.1590/S0104-66322012000400006

Vilela CAA, Artur PO (2008) Secagem do açafrão (Curcuma longa L.) em diferentes cortes geométricos. Ciência e Tecnologia de Alimentos 28(2):387-394. DOI: http://dx.doi.org/10.1590/S0101-20612008000200018 